\title{
FODDER BEANS (VICIA FABA MINOR) AND PEAS (PISUM SATIVUM) IN DAIRY COWS FEED RATIONS
}

\author{
Aiga Trupa, Baiba Osmane, Liga Proskina \\ Latvia University of Agriculture \\ aiga.trupa@1lu.lv, baiba.osmane@arei.lv
}

\begin{abstract}
Holstein-Friesian Black-and-White cows with analogous characteristics were selected and randomly allocated into 4 groups (control and trials), 5 animals each. In vitro digestibility tests of the legumes (peas and fodder beans) are high from $80.50 \%$ to $84.20 \%$. The feed ration digestibility study results show, that on average higher dry matter digestibility was in the $2^{\text {nd }}$ group $-69.42 \%$, in which the feed ration peas "Bruno" was included, and the $1^{\text {st }}$ trial group $-69.29 \%$, in which the ration peas+beans was included. The highest protein digestibility is also presented by the $2^{\text {nd }}$ trial group of cows $-65.97 \%$ and the $1^{\text {st }}$ trial group of cows $-65.82 \%$. The milk yield decreases for the experimental groups $\left(1^{\text {st }}\right.$ and $\left.2^{\text {nd }}\right)$ were smaller $-0.8 \mathrm{~kg}, 1.3 \mathrm{~kg}$, respectively, compared with the initial stage of the experiment $(p<0.05)$. The changes in productivity are mainly associated with the cows' physiological processes during their lactation and pregnancy cycle.In contrast, group 4 (control) showed a significant decrease in the average daily energy corrected milk yield $(4.9 \mathrm{~kg})$, compared with the initial stage of the trial. Compared with the control group, none of the dietary interventions showed significant $(p>0.05)$ deviations.
\end{abstract}

Keywords: beans, peas, in vitro digestibility, dairy cows, productivity.

\section{Introduction}

In the animal feed industry the use of legumes as a source of protein is expected to increase further in the near future. In many animal production systems feed has the biggest single cost and profitability can depend on the relative cost and nutritive value of the feeds available. In pursuit of sustainable and economically-viable farming systems, there is a need for livestock farmers to reduce reliance on imported feed stuffs, such as soya beans, which are subject to world market price fluctuations and have a high environmental footprint. Moreover, most protein crops are legumes and are therefore very interesting for crop rotation for dairy cow farmers and, overall, for sustainability The rumen degradability and the soluble fractions (albumins and globulins) of the protein are higher in grain legumes compared with soybean meals (SBM) and thus, grain legumes are more suitable as supplements to low-protein forages. Consequently, livestock farmers worldwide are under increasing pressure to maximise their use of home-grown feeds $[1 ; 2]$.Therefore, fodder beans and peas can be used as important forage legumes to enhance the feed values for dairy ruminants, especially of importance to today's high yielding dairy cows. In temperate climates, peas (Pisumsativum) and beans (Viciafaba) provide a good source of home grown protein, with peas containing $250 \mathrm{~g} \cdot \mathrm{kg}^{-1}$ crude protein and beans varying between 260 and $300 \mathrm{~g} \cdot \mathrm{kg}^{-1}$. The lysine content of peas and beans is lower than in soya meal. Their relatively high protein content and level of lysine mean that they are complementary to cereals. Field beans have relatively high crude protein level and contain a considerable amount of energy in the form of starch [3], which makes them a unique feed that can be substituted for higher-priced protein and energy commodities like soybean meal (SBM) [1;4]. Digestibility is an important factor of the nutritive value of feed. Digestibility determines the relation between the contents of nutrients and energy that are available to ruminants. Chemical composition of feed provides information about the physical properties and quality of feed and is used to derive digestibility and expected performance of the ruminant receiving the feeds. Digestibility is a measure of the biological availability of nutrients and it is important in formulating a balanced ration in order to obtain maximum productivity in animals. Since digestibility is an important factor to determine the nutritional value of feeds, allowing to establish the relationship between the nutrients content and energy sypply to ruminants, the assessments on forages were based on both nutrient concentration and digestibility. In this sense, methods described in the literature addressed to establish the chemical composition and digestibility, as well as fermentation were adapted for the evaluation of the feed value using in vitro digestion. The digestibility of a feedstuff and the fermentation pattern influences the daily DMI, this is of importance to today's high yielding dairy cows [3-5].The aim of our research was to determine the fodder beans and peas use in dairy cows feed rations. 


\section{Materials and methods}

For the trial, two analogue (according to the yield, lactation phase, live weight, fat content and protein content) groups of 5 animals of Holstein-Friesian Black-and-Whitecows were used in the study. The feeding trial with cows was conducted during the winter period from December 2014 to February 2015 according to the general scheme presented in Table 1 and lasted for 90 days. Preparatory period November1-30 2014.The average live weight of cows was $650 \mathrm{~kg}$, the mean age was 3.0 lactations. The cows of high productivity in the initial phase of lactation were included in the experiment with the average yield of $30.0 \mathrm{~kg}$ per day, fat content $4.10 \%$ and protein content $3.20 \%$, lactation days 60-100. The dairy cows were kept in the same rearing and feeding conditions.

During the trial, the dairy cows received the basic feed ration, which consisted of calculation per cow per day of: $40 \mathrm{~kg}$ silage (grass + legume), $3 \mathrm{~kg}$ hay (grass + legume), $4 \mathrm{~kg}$ fodder (grains), $4 \mathrm{~kg}$ complementary, $0.15 \mathrm{~kg}$ mineral additive. The differences between the trial and control group in feeding were that for the trial group of cows the feed was composed of $1.82 \mathrm{~kg}(0.85 \mathrm{~kg}+0.97 \mathrm{~kg})$ peas + beans ( $1^{\text {st }}$ trial group), $1.90 \mathrm{~kg}$ peas, $\left(2^{\text {nd }}\right.$ trial group) $1.70 \mathrm{~kg}$ beans $\left(3^{\text {rd }}\right.$ trial group$)$ and $1 \mathrm{~kg}$ soybean meal while for the control group (4 group) of cows Table 1 was used.

The feeding ration varied according to each cow's milk yield and physiological state, and was corrected monthly depending on the results of the control milk yield, dry period and state of health. The feeding rations corresponded to the requirements of the zootechnical standards.

Table 1

General scheme of the trials

\begin{tabular}{|c|c|}
\hline Trial group & $\begin{array}{l}\text { Feeding programme } \\
\end{array}$ \\
\hline $1^{\text {st }}$ group & $\begin{array}{c}\text { KF + 10-12\% Pisum sativum"Bruno" + } 10-12 \% \\
\text { Vicia fabaminora"Lielplatone" }\end{array}$ \\
\hline $2^{\text {nd }}$ group & KF $+20-24 \%$ Pisum sativum"Bruno" \\
\hline $3^{\text {rd }}$ group & $\mathrm{KF}+20-24 \%$ Vicia fabaminora "Lielplatone" \\
\hline $4^{\text {th }}$ group (control group) & KF with soybean meal \\
\hline
\end{tabular}

$\mathrm{KF}$ - conventional feed

When elaborating the feeding rations, we took into consideration the following: amount of feedstuffs, dry matter (DM), net energy for lactation (NEL, MJ), amount of crude protein and macroelements (calcium, phosphorus) [6].

In vitro digestibility was estimated for total 9 feed samples: peas "Bruno", fodder beans, fodder peas, soybean meal, rapeseed cake, silage (grass + legume), hay (grass + legume), concentrated feed (meal) and concentrated feed (pellets). In vitro enzymatic digestibility with an enzymatic method and the procedure [7] was conducted by the accredited Scientific Laboratory of the Agronomical Analyses at the Latvia University of Agriculture.

In vitro digestibility method and procedure: a small quantity $(0.3000 \mathrm{~g})$ sample weigh in a tube, add $30 \mathrm{ml}$ pepsin $\mathrm{H} \mathrm{Cl}$ solution. Close the tube with an overpressure cap and incubate at $38{ }^{\circ} \mathrm{C}$ during 24 hours and shake twice a day. After $24 \mathrm{~h}$ put the tubes during 45 minutes in a warm water bath at $80{ }^{\circ} \mathrm{C}$. Suck the solution and wash 3 times with water of $60^{\circ} \mathrm{C}$ and add $30 \mathrm{ml}$ buffered cellulose solution. Incubate at $39^{\circ} \mathrm{C}$ during 24 hours and shake twice a day, filtrate in a sintered glass crucible and wash 3 times with water of $60^{\circ} \mathrm{C}$. Dry at $103^{\circ} \mathrm{C}$ until constant weight. Cool in an exsiccator and weigh to $0.1 \mathrm{mg}$ precision. Ash for at least 2 hours at $550{ }^{\circ} \mathrm{C}$ until constant weight. Cool in the exsiccator and weigh again to $0.1 \mathrm{mg}$ precision. Calculation the enzymatic:

$$
\text { DCom }=100 \times\left(1-\frac{(A-B) \times 1000}{(C-D) \times 0.300}\right),
$$

where DCom-digestibility, \%;

$A$ - mass of the crucible + residue after drying;

$B$ - mass of the crucible + residue after ashing;

$C$ - absolute dry matter in $\mathrm{g} \cdot \mathrm{kg}^{-1}$;

$D-$ ash in $\mathrm{g} \cdot \mathrm{kg}^{-1}$. 
In each run, 3 standard samples are included to correct for fluctuances in enzyme activity. Digestibility of dry matter and protein in feed rations was calculated regarding the consumed feed amount by cows per day, the chemical content of forage and in vitro digestibility indices of feedstuffs.

At the beginning of the experiment, each cow was controlled for the milk yield, as well as for the milk fat and protein content. The quantity of milk produced was evaluated by measuring the productivity - standard litres of energy corrected milk - which was calculated by the following formula [8].

$$
E C M=\text { Milk Yield } \times \frac{0.383 \times \text { Milk Fat }, \%+0.242 \times \text { Milk Protein }, \%+0.7832}{3.14},
$$

where $E C M$ - energy corrected milk.

Milk quality analyzes were performed determining the milk fat and protein content, the method ISO 9622-2013 (E) / IDF 141: 2013 (E). Milk samples for analysis were taken 3 months before trial and once a month during the trial.The biometric data were processed using the computer program SPSS 16.0. Data were analyzed by: Mann-Whitney test at significance level 0.05 to define differences in comparison to the control group and Wilcoxon signed-rank test to define differences between the data atthe start and end of the experiment at significance level $(p<0.05)$.

\section{Results and discussion}

The analysis of feeding rations, consumed by cows during the trials, by their chemical content proved that, generally, the rations meet the demands of standards. Slight differences were found in the provision of mineral elements to all groups of cows. Feed rations to trial cows contained 20.80$21.49 \mathrm{~kg}$ dry matter, 137-143 MJ NEL, 3258-3276 g crude protein, calcium 153-162 $\mathrm{g}$ and 82-85 g phosphorus from the dry matter. In Table2, we can observe the in vitro enzymatic digestibility of feedstuffs. The research results show that, in vitro digestibility tests of the legumes (peas and fodder beans) are high from $80.50 \%$ to $84.20 \%$.

Higher value was observed for fodder peas "Bruno" and fodder peas on average $84.20 \%$ and $83.40 \%$. Other protein sources high in vitro digestibility value were concentrated feed (pellets) $84.80 \%$, concentrated feed (meal) $80.30 \%$, soybean meal $80.03 \%$ and rapeseed cake, on average $77.10 \%$. The lowest digestibility was presented by hay (grass + legume) and silage (grass + legume) on average $62.90 \%$ and $62.70 \%$.

In general, the digestibility of forages decreases with increasing maturity and it is typically lowest during the dry season. Therefore, it is important to determine the feed quality traits, such as digestibility of the dry matter, crude protein to the formulation of balanced rations for ruminants. For ruminants, common ranges of feed digestibility are $45-55 \%$ for crop by-products and range lands; 55$75 \%$ for good pastures, good preserved forages, and grain supplemented forage-based diets; and 75$85 \%$ for grain-based diets fed in feedlots [3;9].

Table 2

In vitro enzymatic digestibility indices of peas, fodder beans and other protein feeds

\begin{tabular}{|c|c|c|}
\hline No. & Feedstuffs & Digestibility, \% \\
\hline 1. & Peas "Bruno" & $84.20 \pm 0.17$ \\
\hline 2. & Fodder beans & $80.50 \pm 0.05$ \\
\hline 3. & Fodder peas & $83.40 \pm 0.60$ \\
\hline 4. & Soybean meal & $80.03 \pm 0.15$ \\
\hline 5. & Rapeseed cake & $77.10 \pm 0.10$ \\
\hline 6. & Silage (grass+legume) & $62.70 \pm 0.19$ \\
\hline 7. & Hay (grass+legume) & $62.90 \pm 0.68$ \\
\hline 8. & Concentrated feed (meal) & $80.30 \pm 0.26$ \\
\hline 9. & Complementary feed (pellets) & $84.80 \pm 0.80$ \\
\hline
\end{tabular}

The studies on nutrient digestibility of dairy cow feed rations are presented in Fig. 1. 


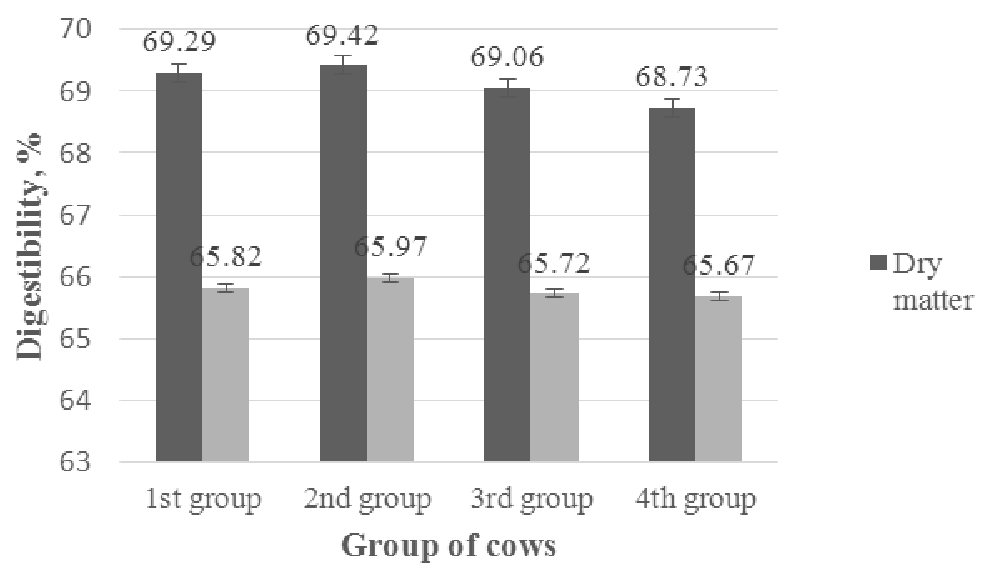

Fig. 1. Dry matter and protein digestibility in dairy cow feed rations, \%

The digestibility study results show that on average higher dry matter digestibility was in the $2^{\text {nd }}$ group, in which the feed ration peas "Bruno" was included, and the $1^{\text {st }}$ trial, in which the ration peas + beans was included. Protein digestibility results show that in groups of cows it is in similar 65.67-65.97\% range. Protein digestibility in the control group of cows was $65.67 \%$, which was lower than for the trial group of cows, respectively by $0.15 \%, 0.30 \%$ and $0.05 \%$. The highest protein digestibility was presented by the $2^{\text {nd }}$ trial group of cows $-65.97 \%$ and the $1^{\text {st }}$ trial group of cows $65.82 \%$. The digestibility study results show that the on average the higher protein digestibility was presented by the groups of cows, which in the feed rations received peas "Bruno" and fodder peas + fodder beans.

The evaluation of the productivity of dairy cows regarding the milk yield showed that the average milk production in all groups of cows during the trial had a decreasing trend, Table 3.

Table 3

Cow productivity during the trials, on average $\mathrm{kg} E C M^{*}$

\begin{tabular}{|c|c|c|c|c|c|}
\hline $\begin{array}{c}\text { Trial } \\
\text { group }\end{array}$ & November** & December & January & February & $\begin{array}{c}\text { Comparison between } \\
\text { initial and final values }\end{array}$ \\
\hline $1^{\text {st }}$ group & $23.8 \pm 6.21$ & $25.4 \pm 5.21$ & $23.7 \pm 3.44$ & $23.0 \pm 2.59$ & -0.8 \\
\hline $2^{\text {nd }}$ group & $25.1 \pm 6.47$ & $23.0 \pm 4.35$ & $22.5 \pm 3.16$ & $23.8 \pm 4.87$ & -1.3 \\
\hline $3^{\text {rd }}$ group & $21.4 \pm 2.08$ & $21.1 \pm 1.35$ & $21.9 \pm 2.28$ & $22.9 \pm 1.58$ & 1.4 \\
\hline $4^{\text {th }}$ group & $27.7 \pm 6.65$ & $27.0 \pm 6.81$ & $22.1 \pm 5.30$ & $22.8 \pm 4.02$ & -4.9 \\
\hline \multicolumn{7}{|c|}{$p-$ value (relative to control) } \\
\hline $\begin{array}{c}\text { Trial } \\
\text { group }\end{array}$ & November** & December & January & February & $\begin{array}{c}\boldsymbol{p} \text {-value (between initial } \\
\text { and final values) }\end{array}$ \\
\hline $1^{\text {st }}$ group & 0.465 & 0.600 & 0.917 & 0.917 & 0.225 \\
\hline $2^{\text {nd }}$ group & 0.917 & 0.347 & 0.917 & 0.754 & 0.138 \\
\hline $3^{\text {rd }}$ group & 0.251 & 0.251 & 0.917 & 0.916 & 0.893 \\
\hline $4^{\text {th }}$ group & - & - & - & - & 0.043 \\
\hline
\end{tabular}

*ECM - energy corrected milk; **_ initial value

Even though the daily milk yields decreased for all cow groups during the experiment, which was normal during the lactation period, yet the milk yield decreases for the experimental groups $\left(1^{\text {st }}\right.$ and $2^{\text {nd }}$ ) were smaller $-0.8 \mathrm{~kg}, 1.3 \mathrm{~kg}$, respectively, compared with the initial stage of the experiment $(p<0.05)$. The changes in productivity are mainly associated with the cows' physiological processes during their lactation and pregnancy cycle [10]. However, group 3 showed increase in the average energy corrected milk yield $(+1.4 \mathrm{~kg})$, compared with the initial stage of the trial and the control group. In contrast, group 4 (control) showed a significant decrease in the average daily energy corrected milk yield $(4.9 \mathrm{~kg})$, compared with the initial stage of the trial. Compared with the control group, none of the dietary interventions showed significant $(p>0.05)$ deviations.

The diet comprising legumes made a positive effect on the protein and fat content of milk during the experiment. The fat and protein content of milk increased for all the experimental groups in 
comparison to the initial values. It positively affects the quantity of milk yield evaluated by standard litres of energy corrected milk $(E C M)$, respectively.

\section{Conclusions}

1. In vitro digestibility tests of the legumes are high from $80.50 \%$ to $84.20 \%$. Higher value was observed for fodder peas "Bruno" and fodder peas, on average $84.20 \%$ and $83.40 \%$.

2. The feed ration digestibility study results show that on average higher dry matter digestibility was in the $2^{\text {nd }}$ group $-69.42 \%$, in which the feed ration peas "Bruno" was included, and the $1^{\text {st }}$ trial, group $-69.29 \%$ in which the ration peas + beans was included. The highest protein digestibility was also presented by the $2^{\text {nd }}$ trial group of cows $-65.97 \%$ and the $1^{\text {st }}$ trial group of cows $65.82 \%$.

3. In total, during the trial, the daily milk yields decreased for all cow groups during the experiment, which was normal during the lactation period, yet the milk yield decreases for the $1^{\text {st }}$ and $2^{\text {nd }}$ experimental groups were smaller $-0.8 \mathrm{~kg}, 1.3 \mathrm{~kg}$ and increased for the $3^{\text {rd }}$ group $-1.4 \mathrm{~kg}$, respectively, compared with the initial stage of the experiment and the control group.

4. The research results proved that the use of legumes as domestic feedstuffs for the purpose of raising the nutritional value of the feed and balancing protein in the feed ration for dairy cows is important and promising, as the legumes help better maintain the milk yield level during the lactation period and enhance the milk quality indicators.

\section{Acknowledgements}

The present work is carried out at the Latvia University of Agriculture and has been supported by the European Seventh Framework Project FPT-KBBE-2013-7. Project No. 613781 "Enhancing of legumes growing in Europe through sustainable cropping for protein supply for food and feed" (EUROLEGUME).

\section{References}

1. Tufarelli, Khan, Laudadio. Evaluating the suitability of field beans as a substitute for soybean meal in early-lactating dairy cow:Production and metabolic responses. Animal Science Journal, vol.83, 2012, pp.136-140.

2. Froidmont E., Bartiaux-Thill N. Suitability of lupin and pea seeds as a substitute for soybean meal in high-producing dairy cow feed. Animal Research, EDP Sciences, vol. 53 (6), 2004, pp. 475-487.

3. Tessema $\mathrm{Z}$ and Baars R. Chemical composition, in vitro dry matter digestibility and ruminal degradation of napier grass pennisetum purpureum. L chumach mixed with different levels of sesbaniasesban L. Merr. Animal Feed Science and Technology, vol. 117, 2004, pp. 29-41.

4. Kudlinskienè I., Gružauskas R., Stankevičius R. etc. Effects of extruded lupins (lupines spp), faba beans (viciafaba) and peas (pisumsativum) on the ruminal fluid parameters in dairy cows. VeterinarijairZootechnika. vol. T. 73 (95), 2016, pp. 88-94.

5. Forejtova J., Lad F., Trinacty J. etc. Comparison of organic matter digestibility determined by in vivo and in vitro methods. J. Anim. Sci., vol. 50, 2005, pp. 47-53.

6. National Research Council (NRC). Nutrient requirements of dairy cattle, 7th revised edn. National Academy Press, Washington, SF203.N883 2001.636.213 p.

7. DeBoever J.L., Cottyn B.G., Andries J.I., Buysse F.X., Vanacker J.M. The use of a cellulose technique to predict digestibility, metabolizable and net energy of forages. Animal Feed Science and Technology, vol. 19, 1988, pp. 247-260.

8. Garcia O., Hemme T., Nho L.T. etc. The economics of milk production in Hanoi, Vietnam, with particular emphasis on small-scale producers. PPLPI Working Paper, vol. 33, 2006, pp. 39-40.

9. Hongmin D., Joe M., Tim A. McAllister.etc. Emissions from livestock and manure management IPCC Guidelines for National Greenhouse Gas Inventories, Chapter 10, 2006. 10.14 p.

10. Volpelli, L.A., Comellini, M., Gozzi, M., Masoero, F. \&Moschini, M. Pea (pisumsativum) and fababeans (viciafaba) in dairy cow diet: Effect on milk production and quality. Italian Journal of Animal Science, vol. 11, 2012, pp. 217-222. 